\title{
モカルペースト添加が食パンの性状および食味に及ぼす影響とその栄養効果
}

\author{
上部光子 $*$ 西成勝好** \\ (*大妻女子大学短期大学部 $\cdot * *$ 大阪市立大学大学院生活科学研究科)
}

\section{Effects of the Addition of Mocal Paste to Bread on the Textural and Nutritional Properties}

\author{
Mitsuko Uwabe*, Katsuyoshi Nishinari**
}

*Junior College Otsuma Women's University, 12, Sanban-cho, Chiyoda-ku, Tokyo, 102-8357

**Osaka City University, Graduate School of Human Life Science, 3-3-138, Sugimoto, Sumiyoshi-ku,

Osaka, $558-8585$

$$
\begin{aligned}
* \text { \% } 102-8357 & \text { 東京都千代田区三番町 } 12 \\
{ }^{*} \overline{\text { T }} 558-8585 & \text { 大阪市住吉区杉本3-3-138 }
\end{aligned}
$$

\begin{abstract}
Mocal paste (MP) is made from okara, a by-product of tofu (soy bean curd), most of which is treated as a waste. The optimum condition of the preparation of bread containing MP was examined. Effects of the quantity of MP on textural and nutritional properties of bread were studied by a simple extension test of the dough, uniaxial compression test of bread, appearance and sensory evaluation. Fracture stress of dough became larger and fracture strain became smaller with increasing content of MP, which led to the low expansibility and small specific volume of the bread. Bread containing excessive MP showed a large compressive stress and did not recover the initial volume after compression. Foam membrame in a crumb of such a bread was thicker than that of breads with less MP. Hardness of a crumb became larger whilst cohesiveness became smaller with the lapse of time and with increasing content of MP. Dough containing MP showed a higher $\mathrm{pH}$ than that without MP, but it was within the range of the optimum $\mathrm{pH}$ rangeca. 5.2. Bread with excessive MP was evaluated more sticky and less resilient in sensory tests. The colour of both the crust and crumb became darker with increasing content of MP. It was concluded that the optimum MP content is $40 \%$ judging from the viewpoint of cooking operation, palatability and nutrition. It is shown that bread containing $40 \%$ MP is rich in protein, fibre, phosphor and potassium in comparison with commercially available bread, and that it is expected to prevent lifestyle related diseases.
\end{abstract}

\section{1. 緒 論}

日本の伝統食品の豆腐は，加工段階においておからを 多量に産出する.このおからは従来, 副食物として食し ていたが，今日では家畜の飼料や肥料に利用され，残り
は産業廃棄物として処理するのに困るところまで追い込 まれている現状である1). そこで環境污染問題解決の一 案として「おから」の有効利用製品が多数考えられてい る. その中の製品の一つがモカルペーストである. モカ ルペーストは, 㧊からに倍量の熱水を加え, マスコロイ 
ダー (石臼のような機械) で摩砕し, 充填 ( $1 \mathrm{~kg}$ 包装)， レトルト滅菌したものである. 栄養的には, たんぱく質 が3.5\%含まれ，エネルギーが51 kcal / $100 \mathrm{~g}$ と低カロ リーである. 特に食物繊維 (5.0\%), カリウムが多く, 家庭での生活習慣病の予防食に大いに役立つ2),3),4)食品 である。

本研究では, モカルペーストを日常食の利用回数の多 い主食用としての食パンに添加した.モカル添加により， より多くの食物繊維，カリウムが摂取できる。一般的に は, 食物䋊維は便秘やガンの予防, また, カリウムは高 血圧の予防に役立つなどの作用があると期待されてい る. また，カリウムは，ゆで調理が多い場合には食品か らの流失が考えられ, この点, 主食として自然に摂取で きれば安心である.

食パンへの「扔から」添加の研究5) は, 製パンへの利 用の研究報告があるのみで, 詳細は報告されていない. そこで, 食パンにモカルを添加し，パンの性状や食味に およぼす影響およびその栄養成分などについて検討し た.

\section{2. 実験方法}

(1) 試 料

小麦粉：(株）日清製粉，スーパーキング（水分 $14.1 \%$, 粗たんぱく質 $13.9 \%$ ，灰分 $0.14 \%)$

モカルペースト：(株）医食同源社〔成分＝水分 $86.9 \%$, たんぱく質 $3.5 \%$, 脂質 $1.7 \%$, 食物繊維 $5.0 \%$, 灰分 $2.3 \%$, 糖質 $4.5 \%$ ]

砂糖：(株) 三井製糖, スプーン印上白糖

油脂 : (株) 三井油脂, ショートニング

ドライイースト：サフドライイースト Le saffre フランス 食塩：(株) 関東化学, 特級塩化ナトリウム

\section{(2) 配合割合}

試料の配合割合は, 調理書(6),7)を参考にした。モカル ペースト（以降，モカルと省略）添加パン生地は，小麦 粉に対して0\% (無添加)，20\%，40\%，60\%，80\%の 5 段階を試料とした（表 1 ). なお，予備実験として手 慣れるまで各試料の調整と測定を 2 回〜 3 回繰り返した 後, 本実験として一つの試料につき $3 \sim 4$ 回繰り返し, 平均を算出した.

\section{（3）試料の調製}

油脂以外のパン生地の材料をボールに入れて混合し， 手捏ねでひとをとめにしたのち油脂を混ぜ込み, ドウを 二つ折りにしながら捏ね，200回捏ね（水を加え，捏ね 開始後 10 分間）生地とした。捏ね上がり生地温度は $27^{\circ} \mathrm{C}$
表 1 モカルペーストパン生地配合割合

\begin{tabular}{|c|c|c|c|c|c|c|c|}
\hline \multicolumn{3}{|c|}{$\begin{array}{l}\text { モカルペースト } \\
\text { 小麦粉に対する割合 }(\%)\end{array}$} & $\begin{array}{c}0 \\
(0)\end{array}$ & $\begin{array}{c}20 \\
(28)\end{array}$ & $\begin{array}{c}40 \\
(56)\end{array}$ & $\begin{array}{c}60 \\
(84) \\
\end{array}$ & $\begin{array}{c}80 \\
(113) \\
\end{array}$ \\
\hline \multicolumn{3}{|c|}{ 小麦粉 } & 140 & 140 & 140 & 140 & 140 \\
\hline \multirow{2}{*}{$\begin{array}{l}\text { 水分 } \\
70 \%\end{array}$} & \multicolumn{2}{|c|}{$\begin{array}{l}\text { モカルペースト } \\
\text { 含有水分量 }(\mathrm{g})\end{array}$} & 0 & 24.3 & 48.7 & 73 & 97.3 \\
\hline & \multicolumn{2}{|l|}{ 水道水（ml） } & 98 & 73.7 & 49.3 & 25 & 0.7 \\
\hline \multicolumn{2}{|c|}{ ドライイースト g } & $2 \%$ & 2.8 & 2.8 & 2.8 & 2.8 & 2.8 \\
\hline \multicolumn{2}{|l|}{ 砂糖 } & $5 \%$ & 7 & 7 & 7 & 7 & 7 \\
\hline \multicolumn{2}{|c|}{ ショートニング g } & $5 \%$ & 7 & 7 & 7 & 7 & 7 \\
\hline \multicolumn{2}{|l|}{ 食塩 } & $1.5 \%$ & 2.1 & 2.1 & 2.1 & 2.1 & 2.1 \\
\hline
\end{tabular}

注）\%は小麦粉に対する割合

に調整した.

恒温恒湿器〔(株) ヤマト科学, IG-42M) で生地の 1 次発酵 $\left(27^{\circ} \mathrm{C}\right.$, 湿度 $\left.85 \%\right)$ ]を 50 分間行いガス抜きを した．ガス抜きは，大きいガス泡を壊して小さい数多く のガス泡に分散させ, 再びガス泡を生長させるために行 うものである ${ }^{8}$.

次に, 生地を丸めてボールに入れてサランラップで覆 い, $25^{\circ} \mathrm{C} \pm 1{ }^{\circ} \mathrm{C}$ (低温恒温器 IL 62) で20分間生地を休 ませた。これは, 分割, 丸めで傷められ, 硬化を起こし た生地を緩和し，生地の表面膜が切れて傷むのを防ぎ， また, 生地が伸びやすい状態になりイーストの発生した 炭酸ガスを逃がさず内包し，保持する膜をつくるために 生地を休をせるためである.この時間をべンチタイムと いう9). その後, 1 個 $140 \mathrm{~g}$ に成形して金属製丸型（直 径 $9 \mathrm{~cm}$, 深さ $6.2 \mathrm{~cm})$ で, 2 次発醉 $\left(38^{\circ} \mathrm{C}\right.$, 湿度 $\left.85 \%\right)$ を40分間行い，ガスオーブン〔(株) リンナイ，RBR$350 \mathrm{ENV}$ 型]を用いて $200{ }^{\circ} \mathrm{C} て ゙ 20$ 分間焙燒した.

混捏直後の生地の物性を測定するため, 表 1 の生地配 合割合のイーストを除いた1 / 2量をパン生地と同様に混 捏し試料とした.

\section{(4) 測定項目}

1）生地の膨化率 生地の膨化率を求めるため, 上 記の方法で調製したパン生地から生地 $20 \mathrm{~g}$ を取り分け, 発酵試験管 $(100 \mathrm{~m} 1 \text { の底なしシリンダー })^{10}$ に入れ，パ ン生地の発酵前と 1 次発酵後, 2 次発酵後の容積を測定 した. 発酵後の生地の容積を発酵前の容積で除して膨化 率とした。

2) 比容積 焙焼後, 室温で $23^{\circ} \mathrm{C}\left( \pm 1{ }^{\circ} \mathrm{C}\right) 2$ 時間 放置したパンの体積を, 菜種法11)で測定し, 体積を重量 で除して求めた. 
3) $\mathrm{pH}$ 測定 混捏直後, 1 次発酵後, 2 次発酵後の 生地および焙焼後の各パン $10 \mathrm{~g}$ を乳鉢ですりつぶし, 蒸 溜水を加えて $100 \mathrm{ml}$ とした後，これを 5 分間ホモジナ

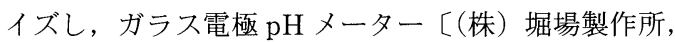
$\mathrm{F}-8 \mathrm{E}$ 〕で測定した.

4 ）パン生地および焙焼後のパンの力学物性測定 イーストを除き試料調製と同様に捏ねた生地を棒状に成 形し，これを直径 $15 \mathrm{~mm}$ ，長さ $20 \mathrm{~mm}$ の筒形に詰め，形を 保つように抜き出しパン生地の試料とした。レオメ一 ター〔(株) 不動工業, レオメーター NRM-2005 J を 用いてこの試料の引張り試験を行い応力, 伸張を測定した.

試料の上面，下面に木製のプランジャーをアロンアル ファーで張り付け, 固定した.このプランジャーを引っ 張り万能型のアダプターに夾んで固定し, 伸張速度 $30 \mathrm{~cm}$ $/ \mathrm{min}$, レンジ $500 \mathrm{~g}$, 終了荷重率 $95 \%$ とした.レオメー ター用解析ソフトにより測定結果を解析した.

焙焼後のパンを布巾で覆い，室温 $23^{\circ} \mathrm{C}\left( \pm 1{ }^{\circ} \mathrm{C}\right)$ に放 冷後, 密閉容器に入れ焙焼後 2 時間ならびに 24 時間低温 恒温器 $23^{\circ} \mathrm{C}\left( \pm 1{ }^{\circ} \mathrm{C}\right)$ で保存した.

パンの直径の中央を縦に切断し, 厚さ $2 \mathrm{~cm}$ の切片を左 右で 1 切れずつ合わせて 2 片の試料を取った. この切片 の中心部分で一辺 $2 \mathrm{~cm}$ の立方体を合わせて $4 \sim 8$ 片とり 試料とした. 試料の切断には, カッター〔(株) 山電, 超音波サンプルカッターUSC-3305]を用いた.

クリープメーター [(株) 山電, レオナーRE-3305] により，テクスチャーモード（くり返し変形にて荷重測 定）で硬さ (圧縮応力), 凝集性（1回目と 2 回目の圧 縮時のエネルギーの比）を測定した. 直径 $40 \mathrm{~mm}$ の板の プランジャーを用い接触面積 $400 \mathrm{~mm}^{2}$, 圧縮速度 $1.0 \mathrm{~mm} / \mathrm{s}$, クリアランス $5 \mathrm{~mm}$ とし

5 ）水分含有率の変化焙焼後のモカルパンを布巾 で覆い冷却したのち, 密閉容器に入れ低温恒温器 $23^{\circ} \mathrm{C}$ $\left( \pm 1{ }^{\circ} \mathrm{C}\right)$ で焙焼直後から 2 時間放置後に測定した. 試 料ごとにパンの中心を軸にして扇型の柱状（20 g ）に切 り分け，これを $3 \mathrm{~mm}$ 角に刻み測定用試料とした。この試 料を $3 \mathrm{~g}$ 計量して $105^{\circ} \mathrm{C}$ 下で水分計〔(株) 島津製作所, EB-280 MOG] を用い加熱乾燥, 重量測定方式で測定 した.

6 ) 内相の断面図焙焼24時間後のパンの直径中央 部〔型: 直径 $9 \mathrm{~cm}$, 深さ $6.2 \mathrm{~cm}$ を縦に切断し, その断 面を $1 \mathrm{~cm}$ 角の方眼状に書いた OHP フィルム上に置きコ ピー機〔(株) コニカ, U-BIX $4355 \mathrm{AF} 〕 て ゙$ 複写した.

7 ) 色 測 モカル添加パンの上表面の中央部之 内部中心部の色については，L， a ，b值を測色色差計
[(株）日本電色工業，ZE2000] を用いて色差 $[=\Delta \mathrm{E}$ (NBS)]を求めた ${ }^{12)}$.

8 ）官能検査焙焼後のモカル添加パンについて, 最も比容積の小さいモカル $80 \%$ 添加パンを除き $0 \%, 20$ $\% ， 40 \% ， 60 \%$ の 4 試料について，順位法を用いクレー マ一検定により解析した ${ }^{13), 14)}$. 評点法は悪い $(-2)$ 〜良い（+2）の 5 段階で行い分散分析を行った.

大妻女子大学食物学科の教職員および学生併せて37名 のパネルで官能検査を行った.

9 ）モカル添加パンの栄養成分 モカル添加 $0 \%$ （無添加）パンとモカル $40 \%$ 添加パンの 2 試料の栄養成 分の分析を日本食品分析センターに依頼した．市販の食 パンについては，四訂日本食品標準成分表を参考 ${ }^{15)} に し$ た.

\section{3. 実験結果および考察}

結果については，一元配置法の分散分析を行い有意差 が見られた要因については，各水準間で母平均の差の検 定を行い検討した.

モカル添加量が，20\%，40\%，60\%，80\%と増すにつ れ, モカル添加パン生地は硬くなり, 捏ね操作中の生地 をまとめることは困難であった．このためモカル添加パ ンとして適量のモカル添加量, 生地の性状, モカル添加 パンの製品の性状および食味におよぼす影響を知るため に実験を行った。

\section{（1）生地の物性}

モカルが増すにつれ，生地は一塊りにまとまりにくく なり，ちぎれやすくなった．それ故，モカル添加がパン 生地の物性にどのように影響するか，応力，伸張歪を測 定した. その結果を図 1 および図 2 に示す.

破断応力の測定値より，0\%（無添加）生地は，モ力 儿添加生地にくらべ, 危険率 $1 \%$ で有意に柔らかいこと が認められた。すべての試料において，モカル添加量が 増すにつれ，危険率 $1 \%$ で有意に硬くなることが認めら れた。

伸張歪について見ると，0\%（無添加）生地は，モカ ル添加生地にくらべ，危険率 $1 \%$ で有意に伸びが良いこ とが認められた．０\%（無添加）生地とモカル20\%添加 生地を比較すると, 危険率 $5 \%$ で有意に $20 \%$ 添加生地の 伸びが悪かった．％（無添加）生地と比較し，40\%， 60\%，80\%は危険率 $1 \%$ で有意に伸びが悪かった． $20 \%$ 添加生地と $40 \%$ 添加生地との間に有意差は認められない が後者の方が伸びが悪かった. 40\%添加生地と60\%添加 生地との間には危険率 $1 \%$ の有意差が認められ，60\%添 


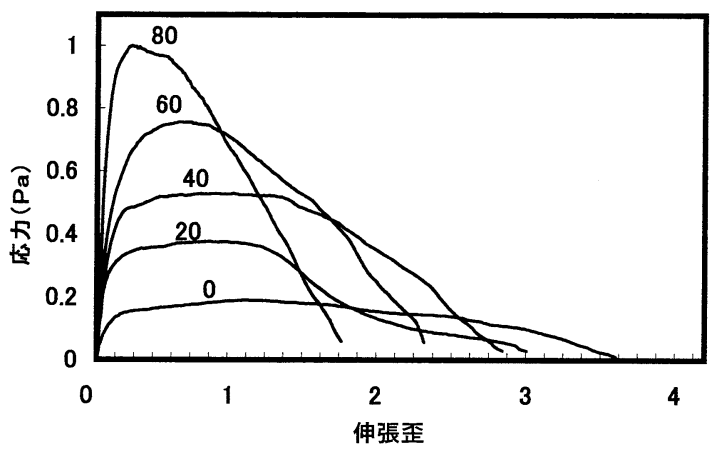

図 1 円柱状（直径 $15 \mathrm{~mm}$, 長さ $20 \mathrm{~mm}$ ) のモカルパン生地の応力 と伸張歪の関係

[数字はモカル添加量の割合 $(\%)$ ]

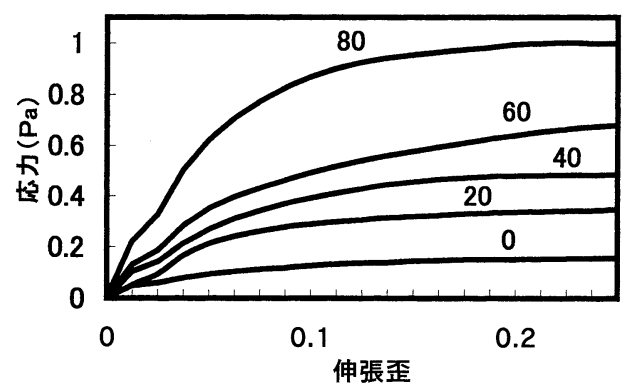

図 2 円柱状（直径 $15 \mathrm{~mm}$, 長さ $20 \mathrm{~mm}$ ) のモカルパン生地の応力 と伸張歪の関係

(初期曲線) [数字はモカル添加量の割合（\%)]

加生地の方が明確に伸びにくいことがわかった．60\%添 加生地と $80 \%$ 添加生地との間には有意差がなく, $80 \%$ 添 加生地の方が伸びにくかった.

$0 \%$ （無添加）生地は，柔らかく，わずかな力によっ ても伸びやすい生地であった，モ力ル添加生地は，モ力 ル量が増すにつれ，破断応力は徐々に高くなり，破断伸 張歪は徐々に小さくなった。つまり, モカル添加量が増 すと, 生地は, 徐々にも万くなった。したがって，モ力 ル添加割合の異なる生地の各試料間では, モカル添加量 が増すにつれ有意に硬いことが示され，また，伸びにく くなった.

以上, $0 \%$ （無添加）生地は, 最も柔らかくしなやか な生地であり, モカル添加生地は, モカル添加量が増す につれ，モカル中の固形分の増加と遊離水の減少により 小麦粉中のたんぱく質との水和がスムースにできず 16),17)，グルテン形成に悪影響を及ぼしていると考えら れた．これがガス包蔵性を徐々に悪くするのではないか と推測された．これらを総合すると, モカル添加パン生

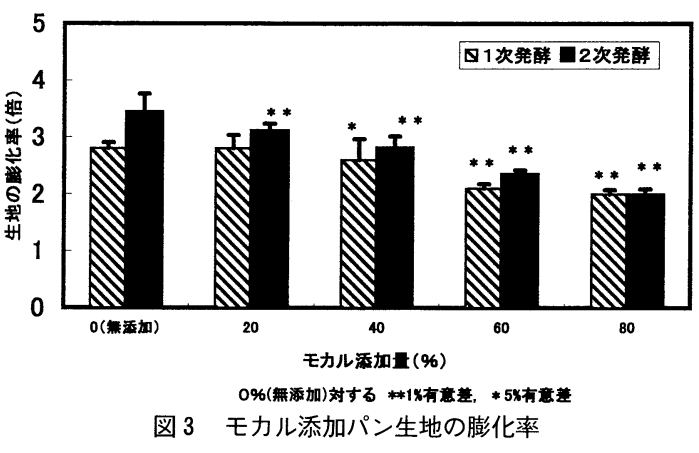

地は $0 \%$ （無添加）生地と比べるとモカル添加生地の伸 びが悪くなった． $40 \%$ 添加と60\%添加の 2 試料間は有意 に60\%の方が伸びにくく, ガス包蔵性が一段と悪いこと が推定され，モカルの添加は $40 \%$ 添加が適当であると考 えられた。

\section{(2) モカル添加生地の膨化率}

モカル添加食パンの生地の膨化率を測定した（図 3 ). $0 \%$ （無添加）パン生地とモカル添加パン生地を比較す ると, 1 次発酵, 2 次発酵ともにモカル添加パン生地の 方が有意に低い膨化率を示した．モカル添加生地の各試 料間では, 添加量が $60 \%$ まではモカル添加量が増すにつ れ有意に膨化が悪く，1次発酵においてモカル添加 $60 \%$ とモカル添加 $80 \%$ の 2 試料間には有意差は認められなか った．すなわち，60\%添加以上では膨化に变化が見られ ず悪い状態であった。

以上， $0 \%$ （無添加）生地に比べモカル添加生地は, 添加量が增すにつれ，1次と 2 次発酵との膨化率の差が 小さくなり悪くなった. また, モカル添加量が少ない生 地では， 2 次発酵の膨化が良好であることが示された. これは, モカル添加量が多くなるとグルテンの形成に悪 影響をおよぼしているためと考えられた。 また, 発酵試 験管中の発酵状態を見ると気泡膜が切れ, グルテン膜の ガス包蔵性の低下が推定された。

\section{（3）モカル添加パンの比容積}

比容積の結果を図 4 に示した. $0 \%$ （無添加）生地パ ンとモカル添加生地パンでは, $1 \%$ の危険率の有意差で モカル添加生地パンの方が比容積が小さいことが認めら れた. モカル添加量が増すにつれ，1\%有意差で比容積 が徐々に小さくなることが認められた。

パン生地へのモカル添加の影響は, 膨化率と同様で, モカル添加量が増すにつれ，比容積にも悪影響を及ぼし ていた.これはすでに前項(1)，(2)において述べたように， モカル添加生地は, 発酵中の炭酸ガスを包むグルテン膜 


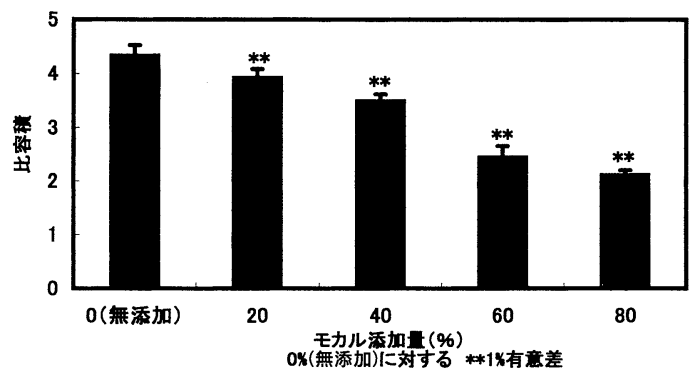

図 4 モカル添加パンの比容積

が弱く膨化率，比容積などに悪影響を及ぼしているため と考えられた。

(4) $\mathrm{pH}$ の変化

モカルの使用時の $\mathrm{pH}$ 值は, $6.3 （ \pm 0.19 ）$ である. このモカル添加が発酵過程中の生地の $\mathrm{pH}$ にどのように 影響するか，混捏直後，1 次発酵後， 2 次発酵後および 焙焼後のパンについて,それぞれの $\mathrm{pH}$ を測定した(図 5 ).

その結果, モカル $0 \%$ （無添加）生地とモカル添加生 地間の $\mathrm{pH}$ を比較すると, モカル添加生地の方が有意に 高い pH を示した．各試料間では，混捏直後の $0 \%$ （無 添加）生地々 $20 \%$ 添加生地，0\%（無添加）生地と $40 \%$ 添加生地打よび焙焼後の $0 \%$ （無添加）パンと $20 \%$ 添加 パンの各 2 試料間に有意差が認められなかった．その他

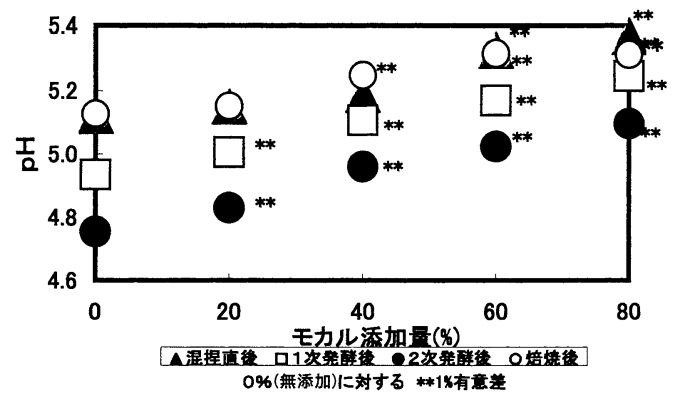

図 5 モカル添加パンの pH

は危険率 $1 \%$ で有意差が認められた．各試料とも発酵時 間が進むにつれ低值を示し, 焙焼後のパン $\mathrm{pH}$ は生地の 混捏直後の值と同程度まで高くなった。

以上, 生地の $\mathrm{pH}$ はモカル添加量が増すにつれ徐々に 高くなった，混捏直後から発酵時間が進むにつれ 1 次発 酵, 2 次発酵の順に低くなった。この生地の $\mathrm{pH}$ の低下 は, 生地中の生酸菌などによる有機酸の生成やイースト フード中のアンモニア塩からの無機酸の生成および酵母 の生成する炭酸ガスの水への溶解による炭酸の生成なぞ によるもの報告されている16). 焙焼後のパンの $\mathrm{pH}$ は，

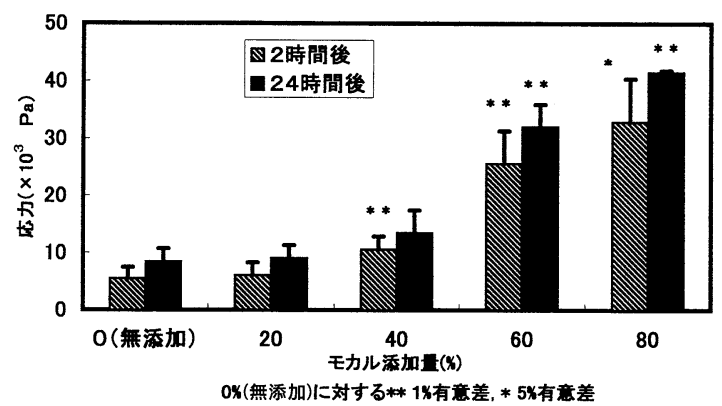

図 6 モカル添加パンの応力（2 cm角の試料を75\%圧縮した）

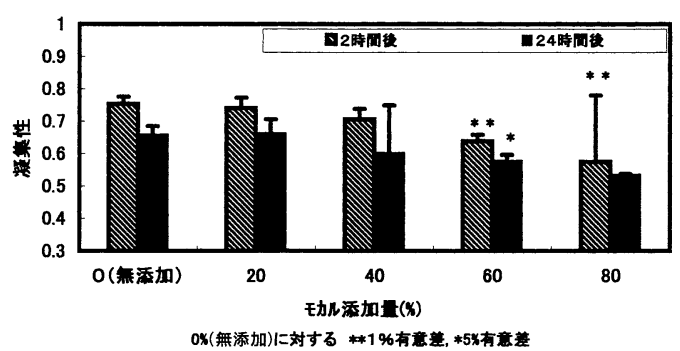

図 7 モカル添加パンの疑集性

混捏直後と同程度まで回復した. 竹谷 ${ }^{18)}$ は, パン生地発 酵の場合の $\mathrm{pH}$ は, 温度範囲が $24 \sim 35^{\circ} \mathrm{C} て ゙ ~ \mathrm{pH} 5.0 \sim 5.8$ であると報告している. 本実験の $\mathrm{pH}$ はこの範囲であり, イースト菌の生育最適条件の $\mathrm{pH} 5.2$ 前後であった。す なわち, モカル添加量が増加するにつれ, 生地の $\mathrm{pH}$ は 高くなったがイースト菌の生育範囲であり, 悪影響を及 ぼすことはないと推測された。

（5）モカル添加パンの圧縮応力と凝集性

焙燒後のパンの 2 時間および 24 時間の経過時間による 力学特性の变化を測定した（図 6, 図 7 ).

焼き上がり 2 時間後の歪み $75 \%$ の圧縮応力を比較する と，0\%（無添加）パンとモカル添加パン間では，モカ ル添加量が増すにつれ, 有意に歪み $75 \%$ の圧縮応力が増 し，硬くなることが認められた。各試料間では，モカル $0 \%$ （無添加）パンとモカル20\%添加パンおよび60\%添 加パンと $80 \%$ 添加パンの各試料間に有意差なし, その他 の試料間では, 危険率 $1 \%$ の有意差ありで徐々にパンの 硬さが増していることが認められた。

焼き上がり 24 時間後の歪み $75 \%$ の圧縮応力は， 2 時間 後より増加し，硬くなった。０％（無添加）パンと $40 \%$ 添加パン, および $20 \%$ 添加パンと $40 \%$ 添加パンは各 2 試 料間に $5 \%$ ，40\%添加パンと60\%添加パンの 2 試料間で は $1 \%$ の危険率でそれぞれ有意差ありと認められた。

以上から $40 \%$ 添加パンと60\%添加パン間の差が大きく 
モカル添加60\%添加パンはパンとして硬く不適当と考え られた。

焼き上がり 2 時間後の凝集性は, モカル $0 \%$ （無添加） パンとモカル添加パンとの試料間は添加量が増すにつれ 有意に低下が認められた. モカル添加パンの各試料間で は，40\%添加パンまでは有意差がなく徐々に凝集性は低 下し，一度変形させた後の回復性が悪くなった。

焼き上がり24時間後の凝集性は，2 時間後より全試料 とも低下した. また, モカル $0 \%$ （無添加）パンとモカ ル添加パンを比較すると, モカル添加パンの方が危険率 $5 \%$ の有意差で回復性が悪かった. モカル添加パンの各 試料間では, $20 \%$ 添加パンと60\%添加パン間などは, 危 険率 $5 \%$ でモカル添加量の多い方が回復性が悪かった. $80 \%$ 添加パンでは, 測定時に圧縮されたまま回復しない 試料もあった． 2 時間後と 24 時間後における歪み $75 \%$ の 圧縮応力と凝集性を調べると, 24時間後の方がモカルが 増すにつれ, 圧縮応力が高く, 凝集性は低下した.

この傾向が最も顕著に見られたのは，80\%添加パンで あった.このパンは, 膨化率が最も低く, 水分率が多い パンであり，モカルの高い保水性によると考えられる. 測定時に圧縮されプランジャーに付着するために回復し ない試料もあった. したがって, モカル添加パンの場合 は, モカル添加量が増加するにつれ, また，焼き上がり 後の時間が経過するにつれて, 硬さは増加し, 凝集性は 低下した.

この結果から, 添加量が多くなると回復力が劣りパン として適さなくなることがわかった. 生地の力学物性の 測定結果と併せて, モカル添加量 $40 \%$ が添加可能な最大 の量と考えられた。

\section{(6) モカル添加パンの水分含有率}

焼き上がり後のモカル添加パンの水分含有率はパンの 食味と柔らかさに大きく影響すると考えられたので，水 分率を測定した（図8）.

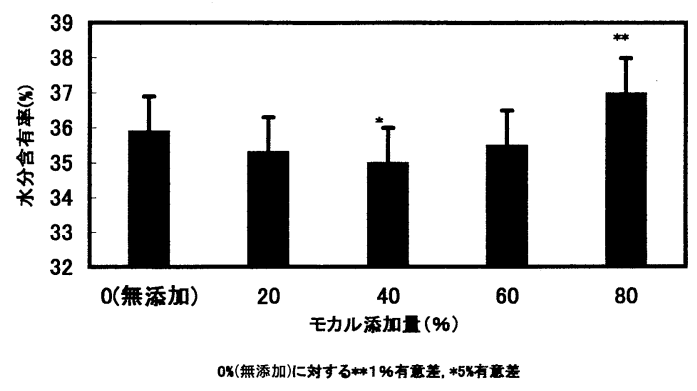

図 8 モカル添加パンの水分含有率
$0 \%$ （無添加）パンとモカル添加パンとを比べると, モカル添加パンでは水分含有率が有意に低かった． $0 \%$ （無添加）パンとモカル $40 \%$ 添加パンの 2 試料間では, モカル $40 \%$ 添加パンの方が $5 \%$ の危険率で有意に低かっ た.

生地の水の割合は, モカルの含有水分を含め一定（70 \%)にした. したがって，モカル量が多くなるとモカル 中の含有水分も多く，不足分として加える水量は少なく なる．このため，モカル $40 \%$ 添加パンまでは遊離水が多 く蒸発しやすい試料である. モカル $80 \%$ 添加パンはモカ ル含有水分のみで遊離水が少ないうえに，モカルの特性 である保水性により，水分含有率が高かったと考えられ た。

\section{（7）色の変化}

モカル添加量の違いにより，焙焼後の色がどのように 変化しているかを測定した．試料は，各モカル添加量ご とに上表面の中央部分とパンの内相の中心部の 2 力所を 試料とした ${ }^{19)}$ (表 2 ).

上表面については，0\%（無添加）パンとモカル添加 パンとの間に L 值 (明るさ), $\mathrm{a}$ 值 (十赤味), $\mathrm{b}$ 值 (+ 黄味）ともに有意差は認められなかった．各試料間を比 較すると，モカル添加量が増加するにつれ， a 值は傾向 が見られなかったが，b值は僅かに高くなる傾向を示し た。

NBS単位で表した色差（ $\Delta \mathrm{E} ）$ と感覚的な差は良く対 応することが知られている ${ }^{12)}$. $\Delta \mathrm{E}$ と感覚との関係は 0 〜0.5（かすかに）, 0.5〜1.5（わずかに）, 1.5〜3.0 (感知せられるほどに), 3.0〜6.0（めだつほどに）, 6.0〜12.0（大いに）, 12.0以上（多大に）で表される. $0 \%$ （無添加）パンとモカル添加20\%添加パン間の差は 「感知せられるほどに」，0％（無添加）パンとモカル 40\%添加パン間は「大いに」，0\%（無添加）パンと60 \%添加パンおよび $0 \%$ （無添加）パンと $80 \%$ 添加パンの 各試料間の差は「目立つほどに」であった． $0 \%$ （無添 加）パンを基準にするとモカル添加パンは，モカルが増 すにつれ，アミノ酸の増加が考えられ，糖とアミノ酸の 共存によりメイラード反応を起こしやすくなり，焼成中 に生ずるカラメル生成反応とあわせて焼き色に影響した ものと考えられた 20),21).

内部中心部では， a , b 值ともに0\%（無添加）パン とモカル添加パンの間に有意差があると認められた.

a 值の試料間では $0 \%$ （無添加）パンと20\%添加パン 間で危険率 $5 \%$ で有意差があり，0％（無添加）パンと 比べモカル添加 $20 \% ， 40 \% ， 60 \% ， 80 \%$ 各試料間は，危 


\begin{tabular}{|c|c|c|c|c|c|}
\hline 測定項目 & 0 & 20 & 40 & 60 & 80 \\
\hline $\mathrm{L}$ 值 & 52.88 & 53.59 & 54.51 & 54.89 & 54.25 \\
\hline $\mathrm{a}$ 值 & 15.18 & 15.13 & 14.57 & 14.78 & 15.35 \\
\hline $\mathrm{b}$ 值 & 33.73 & 33.51 & 33.21 & 34.17 & 34.34 \\
\hline$\triangle \mathrm{E}(\mathrm{NBS})$ & & 3.01 & 6.95 & 5.55 & 5.52 \\
\hline \multicolumn{6}{|l|}{ 内部中心部 } \\
\hline 測定項目 & 0 & 20 & 40 & 60 & 80 \\
\hline L值 & 76.80 & 76.71 & 75.59 & 75.55 & 74.77 \\
\hline $\mathrm{a}$ 值 & -0.74 & 0.16 & 0.96 & 1.81 & 2.69 \\
\hline b 值 & 18.74 & 19.79 & 21.48 & 22.30 & 25.44 \\
\hline \multicolumn{2}{|l|}{$\Delta \mathrm{E}(\mathrm{NBS})$} & 2.43 & 3.762 & 4.89 & 6.28 \\
\hline
\end{tabular}

モカル添加量は添加割合（\%)

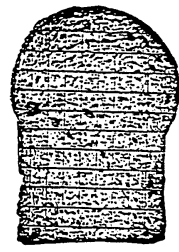

0

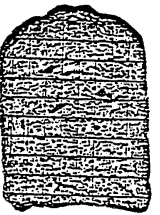

20

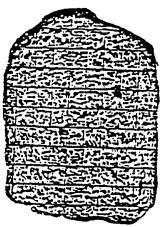

40

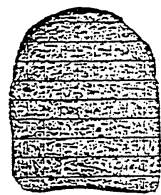

60

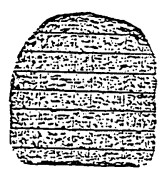

80

モカル潦加割合 $(\%)$

図 9 モカル添加パンの内相

険率 $1 \%$ で有意差が認められた. b 值では $0 \%$ (無添加) パンと $60 \%$ 添加パン，40\%添加パンと $80 \%$ 添加パン間で $5 \%$ 並びに $0 \%$ （無添加）パンとモカル $80 \%$ 添加パン, $20 \%$ 添加パンと $80 \%$ 添加パンの各試料間に $1 \%$ 危険率で 有意差が認められた。 モカル $40 \%$ 添加パンまでは, 内相 の色に大きく影響しないが，モカル $60 \%$ 添加以上の添加 により, 赤味と黄味が増加し，モカルの大豆色に僅かな がら変化したことが示された。

色差（ $\Delta \mathrm{E} ）$ と感覚との関係で比較すると，0\%（無 添加）パンとモカル $20 \%$ 添加パン間の差は「感知せられ るほどに」，0\%と40\%添加パンならびに0\%と60\%添 加パン各試料間の差は「目立つほどに」，0\%（無添加） と $80 \%$ 添加パンの試料間の差は「大いに」であった.

モカル添加パンでは, 上表面と内相ともにモカル添加 より徐々に大豆色が増加した. 上表面の $\mathrm{L}, \mathrm{a}, \mathrm{b}$ 值に は, 僅に焼成中のカラメル生成反応やメイラード反応に よる影響が現れたと考えられる。

\section{（8） 内相の断面}

モカル添加量 $0 \%$ (無添加)，20\%，40\%，60\%，80 $\%$ の焙焼後のパンの断面をコピー機で複写したものを （図 9）に示す.

$0 \%$ （無添加）パンは膨れあがり，高さがあり，気泡 は棈円形で大きく, 肉眼で見ると気泡膜が薄く膨化が良 好であった. モカル添加パンは, 添加量の増加とともに 徐々に高さが低くなり, モカル $60 \%$ 添加以上では細かい 気泡が詰まった重い状態であり, 肉眼で見ると気泡膜が 厚く感じられ, グルテン膜の伸びが悪いことが推定され た. モカル $40 \%$ 添加パンまでは, 気泡膜にやや透明感が 感じられ60\%添加パンより良好であった.

\section{(9) モカル添加パンの栄養成分}

モカル $0 \%$ (無添加) パンとモカル $40 \%$ 添加パン及び 市販食パンの栄養成分を表 3 に示す。

モカル $40 \%$ 添加パンは，0％（無添加）パン並びに市 販食パンに比べ，たんぱく質，脂質，食物繊維，リン， 
表 3 モカル添加パンの栄養成分

\begin{tabular}{|c|c|c|c|}
\hline 成分 & $\begin{array}{l}\text { モカル } \\
0 \% \text { (無添加) }\end{array}$ & $\begin{array}{r}\text { モカル添加 } \\
40 \% \\
\end{array}$ & 市販食パン \\
\hline 水分 $\mathrm{g}$ & 36.9 & 37.5 & 38.0 \\
\hline たんぱく質 $\mathrm{g}$ & 10.6 & 10.9 & 8.4 \\
\hline 脂質 $\mathrm{g}$ & 3.8 & 4.3 & 3.8 \\
\hline 灰分 $\mathrm{g}$ & 1.2 & 1.3 & 1.7 \\
\hline 糖質 $\mathrm{g}$ & 47.5 & 45.7 & 48.0 \\
\hline 食物織維 g & 2.5 & 3.6 & 2.3 \\
\hline リン $\mathrm{mg}$ & 81.4 & 88.9 & 70.0 \\
\hline カルシウム $\mathrm{mg}$ & 11.3 & 22.0 & 36.0 \\
\hline カリウム $\mathrm{mg}$ & 88.8 & 123.0 & 95.0 \\
\hline
\end{tabular}

*数字は 100 中の含有量

カリウムなど 5 項目について高い栄養成分を示した．特 に食物繊維はモカル添加 $0 \%$ （無添加）パンの含有量 $2.5 \mathrm{~g}$ に比べ, モカル添加パンは $3.6 \mathrm{~g} / 100 \mathrm{~g}$ 含まれ, 干しそばと同程度, 市販食パンに比べ1.6倍であった. カリウムは, 無添加パンに比べ1.4倍, 市販食パンの 1.3
倍であった．食物繊維は，便秘やガンの予防に役立ち， カリウムは，ゆで調理により失なわれることが多い。 た, 調理済食品の購入回数の増加や外食などによる食塩 の過㮃摂取が危惧されている，そこで，ナトリウムの排 泄作用のあるカリウム含有食品の摂取が生活習慣病予防 のため重視されている．例えばカリウム摂取量の不足あ るいはナトリウムに対する相対的不足は, 高血圧の発症, 進展を促進し, また心筋梗塞, 脳卒中の発症頻度や死亡 率を増加させ，また，カリウム摂取量を増加させると高 血圧患者の血圧が有意に低下するといわれている 4).22).23). したがって, カリウム含有量の多い本実験の モカル添加パンは栄養面で効果的食品と言える.

\section{(10) 官能検査による評価}

モカル添加パンの官能検査の項目は, 味, 香り, 弾力, きめ, 硬さ, 色, 総合など文献10)を参考にした. ただし, ねちゃつきについてはモカルパンの独特の食感を表すも のとして付け加えた. 官能検査の結果をクレーマーの順 位法, 総合評価については評点評価法で処理し解析した。 その結果を表 4 に示す.

モカル $0 \%$ (無添加) パンは, 全項目 で好まれ，モカル60\%添加パンは全項目 で有意に好まれなかった。モモル添加 20 \%添加パンは味，総合評価において $5 \%$ の危険率で有意に好まれた。モカル添加 40\%添加パンは, 硬いと評価されたがモ カル独特のねちゃつきの評価が 2 番目で あり，モカル添加が味わえるパンであっ た．好まれた順位は，0\%（無添加）パ ン, 20\%添加パン，40\%添加パン， $60 \%$ 添加パンであった。

以上, モカル添加パンは, モカルの添 加量が増加しすぎると, 弾力に欠け，も ろく, 硬く，ねちゃつき，しっとりした 重い感じとなり好まれなかった。.モカル 添加パンとしてはモカル添加 $40 \%$ が適当 と思われた。これは, 生地の伸長率やパ ンの比容積において40\%添加と60\%添加 の 2 試料間の差が大きく, $60 \%$ の方が劣 っていることと，官能検査においては20 \%と 40\%は有意差なく，40\%の方がモカ ルの特徵ある独特の食感をもつパンであ るためである.
（）は小麦粉に対するモカルペースト添加量

順位法：クレーマーの検定法 $1 \%$ **，5\% *有意差あり パネル数 37 人：＃はパネル数 16 人 
要 約

モカル添加パンを毎日の食事の主食としてよりおいし いパンにするためにモカル添加量の適量を知り, パンの 品質や性状およびその栄養成分について検討した。

1. パン生地は, モカル $0 \%$ （無添加）では, 破断応 力において最低を示し, 破断伸張丕は最大を示した. モ カル添加量が増すにつれ徐々に破断応力は大きく，破断 伸張歪は小さくなった. したがって, モカル添加生地は, モカル添加量が増すにつれ, 混捏直後では, スムーズに 水和されずグルテンの形成を遅らせ伸びの悪い生地にな ったここのため，40\%添加生地を適当とした．

2. モカル添加生地のpHは, $0 \%$ （無添加）生地よ り高值を示したが，イースト菌の生育の最適条件のpH 5.2 前後で悪影響を与えることはないことがわかった.

3. 比容積は添加量が増すにつれ低值を示した。調理 操作上の生地の取り扱い易さを考慮すると，パンへのモ カル添加量は $40 \%$ が上限と考えられた.

4. モカル添加パンは, モカル添加量が増すにつれ, 膨化率が低く，内相の気泡膜が厚くなる傾向があり，パ ンとして $40 \%$ 添加量が適当と考えられた。

5 . 焼き上がり 2 時間経過後のパンは，24時間経過後 のパンより, 柔らかく回復力が良かった. 24 時間経過後 のパンでは，モカル添加量が多い $80 \%$ 添加パンの水分率 が高かった。

6.上表面では, モカル添加量が増加するにつれ, 僅 かに焼き色が濃くなる傾向を示し, 内相では, 黄味が増 加し, 大豆色を帯びた.

7 . 官能検査の結果は, モカル添加量が多いパンでは, もどりの悪いことから, ねちゃつくと評価された．モカ 儿添加 $60 \%$ 以上は好をれなかったが，モカル添加 $40 \%$ が 良好であった。

8. モカル添加パンの栄養成分は, 無添加パンおよび 市販食パンと比較すると, たんぱく質, 脂質, 食物緎維, リン，カリウムなどの栄養素の含有量が多くなった.

\section{文献}

1）関口良治：食品と科学，33，91，(1991)

2）栄養学ハンドブック編集委員会: 栄養ハンドブック, 技法 堂出版, 東京, p .609, (1985)

3）堀川蘭子他：栄養生理 - 生化学, 朝倉書店, 東京, p .141 (1989)

4）大塚彰 : 高秢者の「食」の援助プログラム, 医歯薬出版, 東京, p.36 (1995)

5）松本憲一, 越智猛夫 : 大妻女子大学紀要一家政系一，33, 東京, p.62 (1997)

6) 中沢久：パンづくりノート, 柴田書店, 東京, p.35 (1990)

7）岩田弘和: ベーカリー技術百科 2 , 新しいパンづくり「基 本パン」, ダイレック社, 東京, p.11 (1989)

8）松本博: パン膨脹についての基礎的な諸研究, 日本調理科 学会誌 14, 217 (1981)

9）岩田弘和：ベーカリー技術百科 I , 新しいパンづくり「基 礎技術」,ダイレック社, 東京, p .103 (1995)

10）中里卜シ子, 下坂智恵, 松井能子: 日本調理科学会誌, 24, 217 (1991)

11）山崎清子著 : 調理実験, 同文書院, 東京, p .7 (1997)

12）山崎清子著 : 調理実験, 同文書院, 東京, p .194（1997）

13）佐藤信：官能検査入門，日科技連，東京， p .230 (1986)

14）野呂影勇：官能検査ガイドブック，東京，p .230（1991）

15）科学技術庁資源調査会: 四訂日本食品標準成分表, 大蔵省 印刷局, 東京 (1982)

16）田中康夫, 松本博 : 製パンプロセスの科学, 光琳, 東京, $\mathrm{p} .27, \mathrm{p} 106$ (1991)

17) 杉田浩一：調理の科学, 医霜薬出版, 東京, p .209 (1967)

18）竹谷光司: 新しい製パソ基礎知識, パンニュース社, 東京, p.35, 110 (1992)

19）吳計春, 相良泰行, 瀬尾泰久, 森嶋博: 日本食品科学工学 学会誌 44, 31 (1997)

20）清水弘熙: アメリカ小麦食品普及所（訳者），小麦粉麦か らパソヘ: 東京, p.48 (1973)

21）大木道則, 大沢利昭, 田中元治, 千原秀明 : 化学大辞典, 東京化学同人, 東京, p .2312 (1989)

22）中原澄男: 公衆栄養と栄養指導, 第一出版, 東京, p.146 (1992)

23）日本調理科学会編: 総合調理科学事典, 光生館, 東京, $p$. 150 (1997) 